\title{
ZAMEK I KLASZTOR OYBIN. STUDIUM ARCHEOLOGICZNE
}

\author{
THE OYBIN CASTLE AND MONASTERY. \\ AN ARCHAEOLOGICAL STUDY
}

\author{
(autoreferat wygłoszony w trakcie obrony pracy doktorskiej \\ w dniu 29 listopada 2007 r.).
}

\begin{abstract}
Zasadniczym celem niniejszej pracy jest możliwie pełne prześledzenie dziejów zamku i klasztoru w Oybin, oparte przede wszystkim na dostępnych informacjach źródłowych, które pozyskano $w$ trakcie archeologiczno-architektonicznych badań przeprowadzonych na ich terenie w latach 1992-2000. Analizie poddany został ruchomy oraz nieruchomy materiał, który odsłonięto nie tylko w trakcie regularnych prac nadzorowanych przez Krajowy Urząd Archeologiczny Saksonii (Landesamt für Archäologie Sachsen), ale także pochodzący z wykopów niekontrolowanych przez archeologów oraz ze znalezisk powierzchniowych. Celem szczegółowego opracowania tych obiektów było uzyskanie jak najpełniejszych danych na temat urbanistycznego rozplanowania zabudowań należących do zamku i klasztoru oraz wyciągnięcie wniosków na temat wyposażenia używanego przez ich mieszkańców.

Zainteresowanie przeszłością zamku i klasztoru Oybin sięga już XVIII w., niemniej jednak dotychczas oba obiekty nie doczekały wyczerpujących opracowań monograficznych. Oprócz pierwszych publikacji zawierających głównie studia nad zachowanymi źródłami pisanymi oraz ich, nie zawsze rzetelną, interpretację, ukazały się w ostatnim dziesięcioleciu pojedyncze prace prezentujące wyniki badań archeologicznych. Należy jednak podkreślić, że opracowania te, a szczególnie pozycje dotyczące analizy archiwaliów, stanowiły w dużej mierze niezbędne dla niniejszej pracy oparcie dla dokonania interpretacji obiektów odsłoniętych w trakcie badań archeologicznych.

Ramy chronologiczne niniejszych rozważań wyznacza okres powstania na górze Oybin pierwszej zabudowy obronnej, przypadający na 2. poł. XIII w. oraz upadek działalności wznoszącego się na niej klasztoru celestynów, który nastąpił w 2. poł. XVI w.

Miejscowość Oybin (obecnie Kurort Oybin) leży w Górach Żytawskich, około $7,5 \mathrm{~km}$ na południowy zachód od miasta Żytawa (niem. Zittau). Tereny dawnej ziemi żytawskiej zajmują obecnie południowo-wschodni obszar niemieckiego landu Saksonia.

Nazwa Oybin wywodzi się prawdopodobnie jeszcze z czasów słowiańskiego osadnictwa. Przyjmuje się, że najstarsza przekazana przez źródła forma, czyli Moibin stano-
\end{abstract}


wi pierwowzór obecnie używanego miana. Pierwszy przekaz pisemny wymieniający Oybin pochodzi dopiero z $1290 \mathrm{r}$. W jednym z aktów darowizny wspomina się Ztenka z Moibin jako świadka. Ziemia żytawska, obejmująca swym zasięgiem również górę Oybin, zarządzana była od XIII w. przez „panów na Żytawie” - członków możnego czeskiego rodu Hronowiców, do którego to należał wspomniany Ztenko. Według kroniki sporządzonej w XIV w. przez pisarza miejskiego Johannesa z Gubina, wzniesienie pierwszej zabudowy na górze Oybin zarządził jeden z przedstawicieli tego rodu - Chwalo, któremu te tereny podlegały w 2 . poł. XIII w.

W wyniku rozbudowy, którą przeprowadzono prawdopodobnie na początku XIV w., pierwotny zamek został poszerzony o szereg nowych elementów, zgrupowanych głównie w północno-wschodniej części masywu góry Oybin. Wspomniany kronikarz żytawski Johannes z Gubina przyporządkowuje przeprowadzenie tych szeroko zakrojonych prac baronowi czeskiemu Henrykowi z Lipy, który w 1310 r. otrzymał te tereny w lenno od niemieckiego króla Henryka VII. Już wkrótce, bo w 1319 r., nastąpiła zmiana bezpośrednich właścicieli ziemi żytawskiej oraz przynależnych do niej zamków. Zwierzchnictwo nad nimi przejął król czeski Jan Luksemburski, który jeszcze w tym samym roku przekazał zamek Oybin księciu śląskiemu Henrykowi z Jawora. W wyniku obustronnych układów zamek Oybin powrócił ponownie w 1346 r. pod rządy króla czeskiego Jana Luksemburskiego, a następnie jego syna i następcy Karola IV.

Okres 1. poł. XIV w. stanowi istotny etap w historii zamku Oybin, charakteryzujący się nie tylko licznymi pracami budowlanymi, ale i zmianą dotychczasowego przeznaczenia. Z rozkazu Karola IV miasto Żytawa zobowiązane zostało w 1364 r. do rozpoczęcia budowy rezydencji cesarskiej, podnoszącej komfort oraz reprezentacyjność całego założenia. Następną ważną datę stanowił rok 1366, w którym to Karol IV ufundował na górze Oybin nowy klasztor dla zakonu celestynów - kongregacji benedyktynów założonej przez Piotra z Morrone (późniejszego papieża Celestyna V). Ukończony budynek kościoła klasztornego został poświęcony w dniu 6 listopada 1384 r. przez arcybiskupa praskiego Jana z Jenstein. Zgodnie z zapisem w dokumencie fundacyjnym część budynków wchodzących dotychczas w skład zamku przekazano na potrzeby klasztoru.

Do kolejnych wydarzeń, mających wpływ na losy tego zespołu, doszło w 1. poł. XV w. Podczas zamieszek husyckich na terenie Królestwa Czeskiego przechowywano w Oybinie, od 1421 do 1440 r., cenne relikwie z praskiej katedry. Sam zamek i klasztor Oybin odparły skutecznie w roku 1420 oraz 1429 - oblężenie wojsk husyckich. Z początkiem XVI w. klasztor stopniowo upadał, czego główną przyczyną była szerząca się na terenach czeskich reformacja. W roku 1555 umarł w Żytawie Christoph Uthmann - ostatni przeor klasztoru. Po nieudanych próbach przeciwstawienia się nowym ruchom religijnym jezuici prascy zlikwidowali ostatecznie w $1556 \mathrm{r}$. klasztor na górze Oybin. W $1574 \mathrm{r}$. zabudowania zamku Oybin ponownie przeszły w posiadanie miasta Żytawa. Po pożarze w 1577 r. oraz osunięciu się skał w 1681 r. definitywnie opuszczono jego zabudowania.

W ciągu rodzącego się w ostatnich dwóch stuleciach żywego zainteresowania przeszłością własnego kraju ponownie odkryto walory malowniczych ruin na górze Oybin, 
urządzając do nich liczne wycieczki. Sławni malarze okresu romantyzmu, jak: Casper David Friedrich, Carl Gustav Carus oraz Ludwig Richter stworzyli dzieła przedstawiające motywy zachowanej architektury zamku i klasztoru Oybin na tle otaczającej ją przyrody.

Prace restauratorskie na zamku i klasztorze Oybin rozpoczęto z inicjatywy Gminy Oybin w 1992 r. W ich trakcie usuwano warstwy zalegające przy obiektach architektonicznych, które zamierzano poddać zabiegom konserwatorskim oraz odgruzowywano pomieszczenia piwniczne. Nadzór archeologiczny nad tymi pracami przeprowadzony był początkowo przez osoby prywatne z polecenia Gminy Oybin oraz Urzędu Ochrony Zabytków w Dreźnie (Landesamt für Denkmalpflege Sachsen), a od 1997 r. został przejęty przez Krajowy Urząd Archeologiczny w Dreźnie (Landesamt für Archäologie Sachsen). Badania archeologiczne koncentrowały się głównie na terenie tzw. zamku głównego. W mniejszym stopniu objęto nimi obszar międzymurza oraz przedzamcza, co negatywnie wpłynęło na możliwość całościowego rozpoznania zabudowy tej części kompleksu. Wynikało to z konieczności ścisłego dostosowania zasięgu wykopów badawczych do zakresu prac konserwatorskich, powodując ograniczenie intencji samych archeologów objęcia kompleksową eksploracją obiektów ważnych pod względem poznawczym. W niniejszej pracy podjęto po raz pierwszy zebranie całej dokumentacji wykonanej przez wymienione ośrodki oraz uzupełnienie często rozproszonych informacji na temat dokonanych prac ziemnych.

Analiza bogatego materiału źródłowego, pozyskanego przede wszystkim podczas badań archeologicznych, pozwoliła na podjęcie próby rekonstrukcji poszczególnych faz rozwoju założenia zamku i klasztoru Oybin. W jej wyniku uzyskano najwięcej informacji dotyczących okresu rozkwitu działalności klasztoru celestynów oraz bezpośrednio poprzedzającej go fazy rozbudowy zamku z inicjatywy Karola IV. Okresy wcześniejsze związane z administrowaniem ziemią żytawską w XIII oraz w 1. poł. XIV w. przez członków rodu Hronowiców, a także możnowładców czeskich, zostały w mniejszym stopniu rozpoznane. W celu uzupełnienia danych wynikających z prac archeologicznych odniesiono się ponadto do wiadomości pochodzących ze źródeł pisanych. Takie postępowanie umożliwiło wydzielenie pięciu faz budowlanych w dziejach zamku i klasztoru Oybin, powiązanych z konkretnymi wydarzeniami historycznymi:

1) zamek pierwotny - tzw. zamek Lipy I - 2. poł. XIII w./pocz. XIV w.,

2) pierwsza rozbudowa - tzw. zamek Lipy II - 1. poł. XIV w.,

3) druga rozbudowa - wzniesienie rezydencji cesarskiej - 2. poł. XIV w.,

4) trzecia rozbudowa - fundacja klasztoru celestynów - 2. poł. XIV w. oraz wiek XV,

5) czwarta rozbudowa - koniec XV w. oraz 1. poł. XVI w.

\section{Zamek pierwotny - zamek Lipy I}

Na podstawie treści wzmianek w zachowanych źródłach pisanych, zwłaszcza w sporządzonej między 1363 a 1387 rokiem kronice Johannesa z Gubina, jak i uwzględniając polityczno-gospodarcze przemiany, które nastąpiły na ziemi żytawskiej w 2. poł. XIII w. 
należy przyjąć, że w okresie zarządzania tymi obszarami przez braci Chwala oraz Ztenka z rodu Hronowiców nastąpiło wzmożone zainteresowanie obszarem góry Oybin. Przypuszczalnie właśnie w tej fazie, nazwanej w ramach niniejszego opracowania ,zamkiem Lipy I", wzniesione zostały najstarsze jego części. Okres ten związany był z formowaniem się nowych miast przy szlakach handlowych, w tym Żytawy, co wpłynęło zapewne na budowę obiektów obronnych, zapewniających bezpieczeństwo przemieszczającym się kupcom. Należy zatem przyjąć, że właśnie z tej przyczyny wykorzystano naturalne walory obronne góry Oybin, usytuowanej bezpośrednio przy szlaku Leipaer Straße, wznosząc na niej w 2. poł. XIII w. pierwsze umocnienie.

Rekonstrukcja zabudowań zamku Lipy I z fazy pierwszej, opierająca się na źródłach archeologicznych oraz architektonicznych, sprawia najwięcej trudności. Ze względu na nielicznie zachowane najstarsze obiekty, rozważania na temat ich rozplanowania mają w dużej mierze charakter hipotetyczny. Należałoby jednak przyjąć, że większość budynków mieściła się w zachodniej części południowego masywu góry, gdzie dysponowano największą powierzchnią budowlaną. Do najlepiej zachowanych pozostałości zamku Lipy I należy budynek główny, czyli wieża mieszkalna oraz dochodzący do jej południowo-wschodniego narożnika odcinek muru obwodowego, w którym pierwotnie znajdowało się wejście prowadzące do wnętrza zespołu. Relikty przypuszczalnie północnego muru obwodowego uchwycono podczas badań archeologicznych pod budynkiem tzw. kostnicy. Wzniesione w 2. poł. XIII w. umocnienie należało prawdopodobnie do przeważającego na terenach czeskich możnowładczego zamku typu bergfriedowego, czyli do założeń, w których dominujący element stanowiła wieża ostatecznej obrony. $\mathrm{O}$ istnieniu takiej budowli na górze Oybin donosił w kronice Johannes z Gubina, a o jej znieszczeniu w 1681 r. pisał Johann Benedict Carpzov. Budynek wieży ostatecznej obrony zamykał najprawdopodobniej od strony wschodniej obszar zajmowany przez zamek pierwotny.

Zestawiając dostępne dane, można przyjąć, że zamek pierwotny został zbudowany na górze Oybin w okresie wzmożonego wzrostu liczby umocnień możnowładczych na terenach czeskich, przypadającym na 2. poł. XIII w. i składał się z obwodu warownego, wieży mieszkalnej, wieży ostatecznej obrony, być może jeszcze innej zabudowy o trudnej do odtworzenia formie i funkcji.

\section{Pierwsza rozbudowa - tzw. zamek Lipy II -1 . poł. XIV w.}

Próbując odtworzyć rozplanowania zabudowy zamku Lipy II, czyli z okresu administrowania włościami w 1. poł. XIV w. przez Henryka z Lipy oraz jego następcę Henryka Jaworskiego, można opierać się przede wszystkim na informacjach dostarczonych przez źródła pisane oraz na weryfikacji zawartych w nich treści. Tak jak w przypadku fazy zamku pierwotnego brakuje i tu jednoznacznych danych wynikających $\mathrm{z}$ analizy zachowanej substancji architektonicznej oraz wystarczającego rozpoznania archeologicznego.

Załóżmy, że do głównych budynków zamku z 1. poł. XIV w. należały nadal wieża ostatecznej obrony oraz wieża mieszkalna. Nie można jednakże wykluczyć, że z inicjaty- 
wy Henryka z Lipy dokonano gruntowej przebudowy tych obiektów, dostosowując ich konstrukcję do potrzeb nowego właściciela. W tym znaczeniu wzmianka w kronice Johanessa z Gubina o budowie bergfriedu mogła w istocie oznaczać przebudowę lub wzmocnienie konstrukcji wieży wznoszącej się we wschodniej części zamku.

Podczas modernizacji zamku zwiększono prawdopodobnie liczbę elementów obronnych zespołu. Użycie charakterystycznego budulca - kamienia łamanego - pozwala zaliczyć do omawianej fazy objęcie murami obwodowymi przedzamcza oraz międzymurza, a także wzniesienie wież bramnych oraz budynku wartowników. Przypuszczalnie w tym samym okresie wzniesiona została w części północno-wschodniej zamku budowla nazywana potocznie ,kostnicą”. Przyłączenie do zamku nowych terenów na południowo-zachodnim stoku wzniesienia przyczyniło się do poszerzenia istniejących oraz wybudowania nowych obiektów o przeznaczeniu gospodarczym, do których należy zaliczyć m.in. budynek czeladny.

Stan obecnego rozpoznanie źródeł pozwala przyjąć, że pierwszą rozbudowę zamku w Oybin przeprowadzono między 1311 a 1346 r., a największa koncentracja prac budowlanych przypadła na czasy Henryka z Lipy, czyli od 1311 do 1319 r.. Na zabudowę tego zespołu składały się: wieża mieszkalna, wieża ostatecznej obrony, budynek tzw. kostnicy, wewnętrzny mur obwodowy, budynek czeladny, cztery wieże bramne z zewnętrznym murem obwodowym oraz budynkiem wartowników, a także wewnętrzny mur obwodowy międzymurza. Wymienionym obiektom towarzyszyła z pewnością zabudowa gospodarcza, zajmująca głównie południową część założenia.

3. Druga rozbudowa - wzniesienie rezydencji cesarskiej-2. poł. XIV w.

Okres ten, w trakcie którego zmianie uległo kilka zasadniczych elementów założenia zamkowego, stanowi jedną z lepiej źródłowo udokumentowanych faz. W 1346 r. Oybin powraca z resztą posiadłości pod bezpośrednie zwierzchnictwo króla czeskiego Jana Luksemburskiego, a następnie jego syna i następcy Karola IV. Przejęcie władzy przez Karola IV przyniosło istotne przeobrażenie formy architektonicznej zamku Oybin. Pierwszą budowlą, której wznoszenie rozpoczęto z jego rozporządzenia w 1364 r., była rezydencja cesarska. Ten prostokątny, dwupiętrowy budynek wzniesiony został bezpośrednio przy północnej krawędzi zachodniej partii góry Oybin, z fasadą zwróconą w kierunku miasta Żytawa.

W okresie przejmowania zamku przez Karola IV brakowało w nim wystarczającej liczby budynków mieszkalnych, które odpowiadałyby potrzebom oraz związanym z tym miejscem zamiarom nowego właściciela. Należy zatem założyć, że oprócz rezydencji zabudowano w tym samym czasie - przynajmniej częściowo - obszar dziedzińca zamkowego. Podobieństwo zastosowanej techniki murowania pozwala zaliczyć do tej fazy budynek tzw. kancelarii, mieszczący się przy południowej krawędzi wzniesienia.

Rok 1369 stanowi przypuszczalną datę ukończenia gmachu rezydencji cesarskiej oraz wyznacza bezpośrednie przejście do następnej fazy budowlanej, związanej z fundacją klasztoru celestynów. 


\section{Trzecia rozbudowa - fundacja klasztoru celestynów - 2. poł. XIV w. oraz wiek XV}

Okres trzeciej rozbudowy związany jest ze zmianą funkcji zespołu wznoszącego się na terenie góry Oybin. Faza ta jest stosunkowo dobrze udokumentowana źródłami archeologicznymi oraz licznymi przekazami, odnoszącymi się przede wszystkim do sytuacji majątkowej klasztoru celestynów - nowego użytkownika tego miejsca.

Karol IV dokumentem wystawionym w Lucca, 17 marca 1369 r., dokonał fundacji nowego klasztoru kongregacji celestynów na górze Oybin, nazywanego również Mons Paracleti, czyli Góra Ducha Świętego. Cesarz udostępnił zakonowi zabudowania zamku do dowolnego użytku, zachowując jednakże przy Czeskiej Koronie pełne prawa do ich pierwotnej własności.

Okres związany z fundacją oraz działalnością zakonu celestynów to czas najaktywniejszych prac budowlanych. W celu uzyskania dodatkowego miejsca pod wzniesienie kościoła klasztornego zdecydowano się poszerzyć w stronę wschodnią, poza dotychczasową granicę zamku, teren przeznaczony pod budowę. Wygospodarowana w ten sposób przestrzeń umożliwiła wzniesienie jednonawowego kościoła, jego dolnego poziomu (nazywanego kościołem dolnym) oraz ciągu pomieszczeń gospodarczych ze znajdującym się nad nimi piętrem. Przeprowadzone w budynku kościoła badania archeologiczne pozwoliły uchwycić horyzont związany z okresem wznoszenia tej budowli. Dokonano także rozpoznania zachowanych elementów rozplanowania wnętrza świątyni, to znaczy fundamentów ołtarzy bocznych oraz filaru empory zachodniej.

Budynki klauzury tworzyły ciąg zabudowy wznoszący się między rezydencją cesarską a tzw. kostnicą. W trakcie wielosezonowych prac archeologicznych odsłonięto relikty podpiwniczonego budynku wyposażonego w piec typu hipokaustum. Analiza zachowanych detali architektonicznych pozwoliła wywnioskować, że w obiekcie tym mieściło się co najmniej jedno duże, reprezentacyjne pomieszczenie, służące być może zakonnikom jako refektarz.

Następny etap zabudowy obszaru zajmowanego przez klasztor celestynów obejmował postawienie budynku wypełniającego lukę między kościołem i tzw. kostnicą, a także dobudówek przed zachodnią ścianą świątyni. Zespół ten, do którego jedynych pozostałości należą ślady oporów sklepienia oraz falców dachu, zakrywał całkowicie główne wejście do wnętrza kościoła.

Rozplanowanie zabudowy zgrupowanej w zachodniej części masywu góry uległo w ciągu XV w. znacznemu przeobrażeniu. Wolna dotychczas przestrzeń dziedzińca pokryta została zwartą zabudową, która wypełniała lukę między wieżą mieszkalną, budynkiem kancelarii oraz rezydencji cesarskiej. Jak wykazały prace archeologiczne, przed wieżą mieszkalną powstało pomieszczenie przedsionka, co umożliwiło wygospodarowanie dodatkowego ciągu komunikacyjnego. Do trzeciej przebudowy należy zaliczyć również odkrytą przy budynku rezydencji cesarskiej instalację pieca typu hipokaustum oraz przyległe do niego pomieszczenie, pełniące najprawdopodobniej funkcję kuchni.

Kolejne, ważne wydarzenie w dziejach zamku i klasztoru Oybin było podczas wojen husyckich. W trakcie zamieszek i konfliktów, które opanowały Czechy w 1. poł. XV w., 
przechowywano na terenie góry Oybin, od 1421 do 1440 r., relikwie z praskiej katedry. W literaturze przedmiotu uważa się, że miejsce ich zdeponowania mieściło się w przesklepionej piwnicy pod kaplicą św. Wacława. Zagrożenie spowodowane napadami husyckich oddziałów pod przywództwem Prokopa Wielkiego, które w 1420 oraz 1429 r. bezskutecznie szturmowały zamek Oybin, przyczyniło się do zwiększenia obiektów systemu obronnego. Stronę południową zespołu umocniono z dużym prawdopodobieństwem właśnie w tym okresie, dobudowując basztę łupinową do muru obwodowego. Kolejne budowle fortyfikacyjne zaplanowano tym razem na północnym skraju plateau południowego, umacniając jego powierzchnię murem tarczowym oraz flankującą go wieżą zachodnią. Na potrzeby wartowników przysposobiono niewielki budynek, który dobudowano do wschodniego załamania ciągu muru.

Okres obejmujący trzecią przebudowę stanowił najdłuższą fazę, zapoczątkowaną przez przybycie celestynów w 1366 r. na teren góry Oybin oraz ufundowanie w 1369 r. ich klasztoru. W tym czasie całkowicie ukształtowała się struktura zespołu budynków wchodzących w skład zamku i klasztoru Oybin. Do zabudowań wzniesionych w poprzednich fazach dodano obiekty klasztoru mieszczące się przy północnej krawędzi góry, a także na dotychczasowym obszarze dziedzińca zamkowego. Budynki gospodarcze znajdowały się głównie na terenie międzymurza oraz przedzamcza.

\section{Czwarta rozbudowa - koniec XV w. oraz 1. poł. XVI w.}

Wyznaczenie czwartej fazy budowlanej, obejmującej koniec XV oraz 1. poł. XVI w., oparto na nielicznych wzmiankach w źródłach pisanych, a także na informacjach wynikających z badań archeologicznych.

W opracowaniach historii zakonu celestynów w Oybin przyjmuje się zgodnie, że w końcu XV oraz na początku XVI w. przeprowadzono na terenie klasztoru wiele prac budowlanych, obejmujących przede wszystkim zmianę architektonicznego wystroju wnętrz. Izbę przeora około 1494 r. wyposażono w nową oprawę okna, której wykonanie powierzono prawdopodobnie Konradowi Pflügerowi. Analogiczne cechy stylistyczne pozwalają przypisać mu również okno z parteru budynku, wznoszącego się między kościołem i tzw. kostnicą.

Badania archeologiczne uchwyciły fazę ostatniej przebudowy również w budynku klauzury graniczącym z tzw. kostnicą. Pod koniec XV w. wyposażono jego pomieszczenia piwniczne w sklepienia kolebkowe, które zastąpiły dotychczasowe, drewniane stropy, a na znajdującej się wyżej kondygnacji ułożono nowe posadzki.

Wykonanie obejścia obejmującego od południa budynek kościoła klasztornego należało do największych pod względem zasięgu przedsięwzięć podjętych przez zakonników w tej fazie. Wyżłobienie w skale piaskowcowej korytarza o głębokości ponad $11 \mathrm{~m}$ wymagało zapewne ogromnego wysiłku zatrudnionych robotników oraz dużych nakładów finansowych ze strony zakonu. Liczba „1515”, umieszczona na skale poniżej południowej ściany chóru gmachu kościoła, oznacza prawdopodobnie datę jego ukończenia. 
Na skutek szerzącej się na terenach Czech oraz Łużyc reformacji nastąpił szybki upadek działalności klasztoru celestynów. Liczba zakonników przebywających na terenie góry Oybin drastycznie się zmniejszyła, a w 1544 r. pozostali jedynie trzej - Christoph Utmann, Balthasar Gotschalck oraz Martin von Jauer. Dnia 2 września 1555 r. zmarł ostatni przeor zakonu Christoph Utmann, a z momentem przejęcia w 1556 r. zabudowy przez jezuitów praskich nastąpiła stopniowa likwidacja klasztoru celestynów w Oybin.

Ruchome materiały źródłowe, pozyskane podczas badań archeologicznych, oraz zbiory znalezisk luźnych, pozbawionych kontekstu archeologicznego, stały się w niniejszej pracy podstawą dociekań na temat wyposażenia zamku i klasztoru Oybin. Przedstawiony obraz kultury materialnej został oczywiście ograniczony do tych kategorii przedmiotów, które przetrwały do czasów współczesnych i których stan zachowania umożliwił rozpoznanie ich funkcji.

Ceramika naczyniowa, na którą składają się 34023 ułamki, tworzy podstawowy zbiór źródeł ruchomych. Wśród pojemników najliczniej reprezentowana była ceramika określana jako beżowa, o wypale utleniającym. W zbliżonej ilości zarejestrowano szarobrązową i szarobeżową prawiekamionkę oraz ceramikę beżową szkliwioną. Najmniej liczny zbiór stanowiła szarobeżowa kamionka właściwa. Dotychczasowe studia porównawcze wykazały, że zamek i klasztor Oybin był, tak jak analogiczne ośrodki, zaopatrywany w naczynia wytwarzane w okolicznych miejscowościach. Dlatego też opracowanie materiału ceramicznego ze średniowiecznego miejsca produkcji garncarskiej, jakim było miasto Żytawa oraz porównanie go z ceramiką z obszaru północnych Czech, pozwala na przeprowadzenie dokładniejszych badań nad materiałem ceramicznym z terenu Oybin.

Do szczególnie interesującej kategorii znalezisk należały kafle płytowe oraz fragmenty uzbrojenia ochronnego, które odnaleziono podczas odgruzowywania pomieszczeń piwnicznych rezydencji cesarskiej. Na podstawie analizy układu stratygraficznego stwierdzono, że w ich wypełnisku zachowały się elementy wskazujące na pierwotne wyposażenie wnętrz rezydencji. W roku 1577, w wyniku pożaru wywołanego uderzeniem pioruna oraz eksplozji przechowywanego na zamku prochu strzelniczego, zabudowa uległa znacznemu zniszczeniu. Cała konstrukcja kondygnacji wewnętrznych, drewniane podłogi oraz sklepienia runęły wówczas do piwnicy, grzebiąc pod gruzami stojący w jednej z komnat piec kaflowy oraz uzbrojenie przechowywane w jednej z sal. Analiza materiału kaflarskiego umożliwiła określenie czasu wybudowania pieca $\mathrm{w}$ pomieszczeniu rezydencji na 1. poł. XVI w. Płytki tych renesansowych kafli zostały ozdobione przede wszystkim motywami religijnymi, roślinnymi oraz przedstawieniami strojnie odzianych dam dworskich, które mają liczne odpowiedniki na terenach Saksonii, Śląska oraz Czech.

Drugą grupę przedmiotów pozyskanych z tego gruzowiska stanowiły fragmenty uzbrojenia ochronnego oraz pojedyncze egzemplarze broni miotającej. Do tej ostatniej kategorii zaliczono naciąg kuszy, strzemię naciągu oraz grot bełtu, datowane na podstawie analogii na XV w. Odnalezione w Oybinie fragmenty uzbrojenia reprezentują różne elementy pełnej zbroi płytowej. W zespole tym wyróżniono osłonę tułowia w postaci 
napierśnika, naplecznika, obojczyka oraz fartucha. Z grupy obejmującej osłonę rąk pozyskano naramienniki, naręczaki oraz rękawice. Do osłony nóg zaliczono nieliczne części rozpoznane jako elementy konstrukcji nabiodrka. Odpowiedniki uzbrojenia, znane głównie z terenów południowych Niemiec oraz północnych Włoch, umożliwiły zacieśnienie ram chronologicznych tego kompleksu, sytuujących się między 2. poł. XV w., a szczególnie jego czwartą ćwiercią i rokiem 1577, czyli datą pożaru budynków zamku i klasztoru. Sporządzony w 1556 r. spis inwentarza klasztoru wspomina o sali, w której znajdowały się na potrzeby „ośmiu mężów” różne części uzbrojenia. Wzmianka ta może odnosić się do pomieszczenia zbrojowni, mieszącej się w budynku rezydencji cesarskiej, w której zdeponowano część arsenału zamku Oybin.

Przeprowadzony w niniejszej dysertacji przegląd odnalezionych przedmiotów pozwala jedynie na bardzo ograniczone wnioskowanie na temat wyposażenia pomieszczeń oraz zajęć osób zamieszkujących zamek i klasztor Oybin. Charakterystyczna dla tego zbioru jest skromna liczba reprezentowanych kategorii. Najliczniejszą grupę stanowiły gwoździe oraz wytwory związane z konstrukcją budynków i ich elementów, jak drzwi czy okna. W niewielkiej ilości wystąpiły natomiast przedmioty codziennego użytku, które reprezentowane są jedynie przez narzędzia i pojedynczy sprzęt kuchenny. Brakuje natomiast części strojów oraz ozdób, a przede wszystkim przedmiotów kultu. Stan ten pozwala przypuszczać, że po opuszczeniu zabudowań klasztornych w 2. poł. XVI w. i ich postępującemu niszczeniu zabrano przedmioty nadające się do dalszego użytku. Egzemplarze wartościowe, w tym wyposażenie pomieszczeń klasztornych i kościoła, wywieziono natomiast do Pragi.

Zespół zamku i klasztoru Oybin ponad wszelką wątpliwość cechują wybitne walory naukowe. Jest to jedyny w Niemczech przykład bezpośredniego współistnienia obiektu świeckiego oraz sakralnego. Za pomocą analizy źródeł archeologicznych oraz na podstawie dostępnych informacji historycznych, można było prześledzić charakter zabudowy tego zespołu, szczególnie od 2. poł. XIV do 2. poł. XVI w. Natomiast problematyka badawcza związana z początkami tego umocnienia oraz datowaniem zamku pierwotnego jest nadal otwarta. Kontynuowane na tym obiekcie prace archeologiczne oraz postulowane dalsze rozpoznania architektoniczne, a także podjęte badania nad zachowanymi źródłami pisanymi, przyczynią się zapewne do uzupełnienia wiedzy na temat tego tak złożonego kompleksu budowlanego - jednego z najcenniejszych zabytków architektury wznoszącego się na „styku trzech granic”.

\section{EINE ARCHÄOLOGISCHE STUDIE ZUR BURG- UND KLOSTERANLAGE OYBIN}

$$
\text { Zusammenfassung }
$$

Grundlage der Dissertation war die Auswertung der archäologischen Funde und Befunde, die auf der Burg und Klosteranlage der Cölestiner auf dem Berg Oybin in der Oberlausitz (Sachsen, Deutschland) während der Ausgrabungen von 1992 bis 2000 zu Tage gekommen sind. Zu Beginn 
der Dissertation wurden die Geschichte der Anlage und deren heute noch erhaltene Bausubstanz beschrieben. Weiterhin wurden die schriftliche Überlieferung sowie die Forschungsgeschichte zum Oybin zusammenfassend dargestellt. Im folgenden Teil stand die Auswertung der Befundsituation innerhalb des untersuchten Gebietes und der unmittelbar anschließenden Areale im Vordergrund. Dabei wurde auf die gesamte Entwicklung der Burg und des Klosters vom 13. Jahrhundert bis in die zweite Hälfte des 16. Jahrhunderts eingegangen. Abschließend wurde das Fundmaterial nach Fundgattungen gegliedert vorgestellt. Der weitere Dissertationsabschnitt fasste eine Beschreibung der hypothetischen Bauphasen der Anlage auf Grundlage der Befundanalyse zusammen. Der letzte Teil wurde der kulturgeschichtlichen Einordnung der Burg und des Klosters Oybin gewidmet.

Der Beginn der Anlage im späten 13. Jahrhundert ist durch historische Quellen gesichert. Die Auswertung der bisherigen Ausgrabungsergebnisse konnte diese Phase kaum belegen. Die Mehrzahl der Funde wurde in das 15. und 16. Jahrhundert datiert. Zu den spektakulären Fundkomplexen gehören renaissancezeitliche Blattkacheln und Rüstungsteile aus dem 15./16. Jahrhundert.

Im Lichte der archäologischen Untersuchungen stellt sich die Burg- und Klosteranlage Oybin nicht nur als großräumiges, sondern auch multifunktional genutztes Bauwerk dar. Durch die Auswertung der archäologischen Untersuchungen konnten die Erkenntnisse zur Haupt- und Spätphase der Anlage von der zweiten Hälfte des 14. Jahrhunderts bis zur Klosterauflösung in der zweiten Hälfte des 16. Jahrhunderts bedeutend erweitert werden.

Joanna Wojnicz

Landesamt für Archäologie

Zur Wetterwarte 7, 01109 Dresden, Deutschland 